
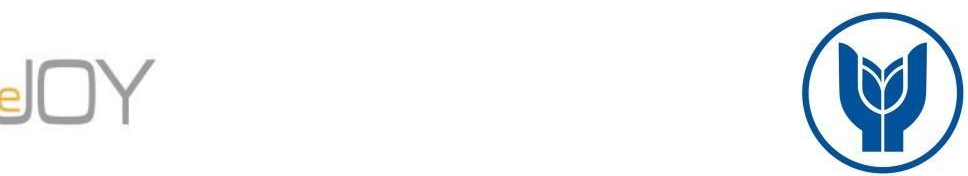

Başaran, M., Ateş, A. / Journal of Yasar University, 2019, 14/54, 87-95

\title{
Kırsal Kalkınmanın Sağlanmasında Kadın İstihdamı: Afyonkarahisar Gazlıgöl Termal Turizm Bölgesi Araştırması
}

\author{
Women's Employment in Providing Rural Development: Afyonkarahisar \\ Gazlıgöl Thermal Tourism Region Research
}

\author{
Mustafa BAŞARAN, Gazlıgöl Havzası Termal Yatırımcılar ve İşletmeleri Derneği, mustafa@basaranlar.com \\ Alper ATEŞ, Selçuk Üniversitesi, Türkiye, alpera@ selcuk.edu.tr
}

\begin{abstract}
Öz: Turizm sektörü, ekonomilere olan çok yönlü katkısının yanı sıra gelişmekte olan ülkelerin bölgelerarası farklllkklarını azaltarak kalkinma için önemli bir firsat oluşturmaktadır. Bu araștırmanın amacı, kırsal kalkinma bölgelerindeki kadın istihdamının incelenerek, olumlu ve olumsuz yönlerini belirlemektir. Araştırma alanı olarak Afyonkarahisar ili Gazlıgöl bölgesindeki termal tesisler belirlenmiştir. Araştırmada, veri toplama yöntemi olarak anket ve mülakat yöntemleri uygulanmıştır. Toplamda 121 anket elde edilmiş ve SPSS 24.0 analiz programı yardımı ile gerçekleştirilmişstir. Mülakatlardan elde edilen ses kayttlarının ve alınan notların raporlanmast ile bulgular elde edilmişstir. Araştırmada, kirsal kalkınma bölgelerinde turizm sektörünün kadınlara önemli istihdam firsatları sunmasına rağmen kadınların iş gücü piyasalarında cinsiyet ayrımı, düşük ücret gibi sorunlarla karşılaşmakta olduğu sonuçlarına ulaşılmıştır. Araştırma sonuçlarına göre kadınların termal tesislerde çalışmasının en önemli nedenleri, ekonomik etkenler ve geçim sorunudur.
\end{abstract}

Anahtar Sözcükler: Kalkınma, Kırsal Kalkınma, Termal Turizm, Kadın İstihdamı, Turizm İstihdamı.

\begin{abstract}
In addition to its multifaceted contribution to the economies, the tourism sector provides an important opportunity for development by reducing the interregional differences of developing countries. The aim of this study is to determine the positive and negative aspects of women's employment in rural development regions. Thermal facilities in the Gazlgöl region of Afyonkarahisar province were determined as the research area. In the research, survey and interview methods were used as data collection method. A total of 121 questionnaires were obtained and were analyzed with the help of SPSS 24.0 analysis program. The findings were obtained by reporting the sound recordings and the notes obtained from the interviews. In the study, although the tourism sector in the rural development regions provided women with significant employment opportunities, it was concluded that women are facing problems such as gender discrimination and low wages in labor markets. According to the research results, the most important reasons for women working in thermal facilities are economic factors and livelihood problem.
\end{abstract}

Keywords: Development, Rural Development, Thermal Tourism, Women's Employment, Tourism Employment.

\section{Giriş}

Turizm sektörü, yapısı gereği mal ve hizmet sunan pek çok farklı sektörün birbirleriyle etkileşimde olduğu, sosyo-kültürel ve çevresel etkileriyle birlikte bir üretim ve tüketim sürecini ifade etmektedir. Bu durumun bir sonucu olarak, özellikle gelişmekte olan ülkeler ve bölgeler açısından turizm sektörü, iktisadi yapıda gerçekleştirdiği dönüşümün yanı sıra sosyokültürel anlamda da bir gelişim sürecini beraberinde getirdiğinden dolayı kalkınmanın temel dinamiği olarak görülmektedir (Bahar, 2013: 5). Ülkelerin kalkınmadan beklentileri, üretim ve hizmet yatırımları ile dağılımlarının en güzel şekilde dönüşümü yansıtabilen bir yerleşim sisteminin kurulmasıdır. Oluşturulan bu sistem ile nüfusun ve sahip olduğu gelirin dağılımı, artışının yanı sıra diğer kaynakların da dengeli bir şekilde kullanılması gereklidir. Turizm sektörü, dünyada en fazla iş sahası oluşturan sektörlerden biri konumunda olup, özellikle gelişmekte olan ülkelerin kalkınma dinamiklerinden biri durumundadır (Ateş vd., 2018: 6592). Dünya Seyahat ve Turizm Konseyi (WTTC) verilerine göre 2013 yılında turizm ve seyahat sektörü, dünya genelinde 267 milyon kişiye doğrudan ve dolaylı iş imkânı sağlamıştır. Bu oran dünyadaki toplam istihdamın \% 8,7'sini denk gelmektedir (Uğuz ve Topbaş, 2014: 497). Kadınların yoğun olarak istihdam edildiği turizm sektörü, dünya GSYH'nin \%10 kadarını oluşturmaktadır (WTTC, 2015; Kaya, 2017: 6). Ekonomiye genel olarak bakıldığında, turizm sektörü kadın istihdamı açısından diğer sektörlere göre daha büyük bir paya sahiptir. Turizm endüstrisinde kadın istihdamı diğer sektörler ile kıyaslandığında iki kat daha fazla istihdam sağlamaktadır (Global Report on Women in Tourism, 2011; Dinçer vd., 2016: 382). Yapılan bu araştırmada kırsal kalkınma ve turizm sektörü ilişkisini incelemek, kırsal bölgelerdeki turizm işlerinde istihdam edilen kadınların sorunlarını ve Afyonkarahisar İli Gazlıgöl termal bölgesindeki tesislerde istihdam edilen kadınların turizm ve turizmde istihdama yönelik algılarını araştırmaktır. Bu amaçlar kapsamında, Gazlıgöl bölgesindeki turizm tesislerinde istihdam edilen 121 kadın çalışana açık ve kapalı uçlu soruların bulunduğu bir anket uygulanmış ve kayıt altına alınan görüşmeler yapılmıştır.

\footnotetext{
${ }^{1}$ Bu çalışma, 2019 yılında Selçuk Üniversitesi Sosyal Bilimler Enstitüsü Seyahat İşletmeciliği ve Turist Rehberliği ABD 'da Dr. Öğr. Üyesi Alper Ateş ve Doç. Dr. Meltem İnce Yenilmez danışmanlıklarında, Mustafa Başaran tarafından hazırlanan "Kırsal Kalkınma Bölgelerinde Kadın İstihdamı: Afyonkarahisar Gazlıgöl Termal Turizm Bölgesi Örneği’” başlıklı yüksek lisans tezinden yararlanılarak hazırlanmıştır.
} 


\section{Kırsal Kalkınma ve Turizm Sektörü}

Kırsal kalkınma kavramı özellikle son yıllarda sıç̧a gündeme gelmesi sonucu bütün insanların mutlu ve refah içerisinde yaşayabileceği bir ortam oluşturmak amacıyla kırsal alanlarda yaşayan insanlara yönelik geliştirilecek kalkınma stratejileri arayışları hızlanmıştır. Geray (1999) kırsal kalkınmayı, kırsal kesimlerde yaşayan insanların sosyal, ekonomik ve kültürel bakımdan mevcut yapısını değiştirecek şekilde üretim, gelir ve refah düzeylerinin iyileştirilmesi, geliştirilmesi, mevcut dengesizliklerin giderilebilmesi, kentsel alanlarda bulunan mevcut fiziksel ve toplumsal altyapının kırsal alanlarda da yapılması, tarımsal ürünlerin daha iyi ve verimli olarak değerlendirilmesi yönündeki süreçleri, etkinlik ve örgütlenmeleri şeklinde ifade etmektedir (Geray, 1999: 63).

Birleşmiş Milletler Örgütü'nün yapmış olduğu tanımlamaya göre kırsal kalkınma; küçük toplulukların içerisinde yer aldıkları ekonomik ve sosyal koşulların iyileştirilmesi amacıyla girişilen çabaların birleştirilmesi, bu toplulukların ulusal anlamda bütünle kaynaştırılması ve ulusal kalkınma çabalarına gerekli ölçüde katkıda bulunmalarının sağlanması sürecini ifade etmektedir (Ahipaşaoğlu ve Çeltek, 2006: 10).

Yapılan kırsal kalkınma çalışmalarında, kırsal kesimlerin yaşadıkları sorunları belirlemekte ve tanımlanmakta, bu sorunlara göre en uygun çözüm önerileri geliştirilerek uygulanmaya çalışılmaktadır. Kırsal kalkınma ile çözülmesine çalışılan bütün sorunlar, geniş ve anlamlı olarak düşünüldüğünde iki ana gruba ayrılmaktadır (Tolunay ve Akyol, 2006: 123). Bunlar;

- Fiziksel sorunlar: Bu gruplamada yer alan sorunlar tamamıla kırsal kesimlerin fiziksel çevresi ile ilgilidir. Bu sorunlara örnek olarak altyapı imkânlarının yeterli düzeyde olmaması, eğitim ve sağlık koşullarında yaşanan olumsuzluklar, tarımsal verimliliğin düşük olması, içme ve sulama suyunun az olması, toprak erozyonu ve benzeri sorunlardır.

- Fiziksel olmayan sorunlar: Bu grupta ye alan sorunlar kırsal kesimlerde içerisinde yaşadıkları bölgedeki ekonomik ve sosyal koşulları sebebiyle meydana gelebilmekte ve ayrıca ülke yönetiminden de kaynaklanabilmektedir. Bu gruptaki sorunlara örnek olarak işlenebilir arazilerin az olması, devlet hizmetlerinin yetersiz kalması veya kırsal kesimlere ulaşamaması, daha fazla toprağı olan çiftçilere bağlılık gösterilebilmesi gibi sorunlardır (Oakley ve Garforth,1985).

\section{Turizm Sektöründe Kadın İstihdamı}

Kadının ücretli birer işçi olarak çalışma hayatına girişi 18. Yüzyılın ikinci yarısında gerçekleşen Sanayi Devrimi ile olmuş, ayrıca II. Dünya Savaşı sonrası hız kazanmıştır (Deane, 1994: 18). Sanayi Devrimi’nin genel olarak iki büyük etkisinden söz etmek mümkündür. Bunlardan birincisi; kadının ücretsiz aile işçiliğinden dışarıya çıkıp ücretli işgücü olarak piyasada yerini almasıyken, İkinci etkisi ise; işgücü piyasasındaki gelişen işgücü arzı ve cinsiyetler arasındaki ilişkinin ön plana çıkmasıdır (Çolak, 2003: 1). II. Dünya Savaşı sonrasında savaş koşulları göz önünde bulundurularak kadınlara yönelik istihdamı artıracak önlemler alınmış ve çalışma hayatında kadın iş gücünün piyasadaki değeri geçicide olsa ön plana çıkmıştır. 1990 yılından itibaren Latin Amerika'da ekonomik anlamda aktif durumda çalışan kadınların \%71'i, Asya ve Pasifik’te \%40, Afrika'da \%20, bunların dışında kalan diğer gelişmiş bölgelerde çalışan kadınların \%62'si hizmet sektöründe çalışması kadın istihdamı açısından oldukça önemlidir (Tokol, 1999: 21).

Turizm sektörü, dünyadaki her on işten birini oluşturan emek yoğun bir hizmet sektörü durumunda olup, dolaylı olarak tarım, inşaat, imalat, el sanatları, finansal hizmetler veya bilgi ve iletişim teknolojileri gibi farklı birçok sektörde değer zinciri rolüyle her beceri seviyesinde iş imkânı oluşturan bir sektör konumundadır (Kaya, 2017: 7). Dünya Seyahat ve Turizm Konseyi (WTTC) verilerine göre 2013 yılında turizm ve seyahat sektörü, dünya genelinde 267 milyon kişiye doğrudan ve dolaylı iş imkânı sağlamıştır. Bu oran dünyadaki toplam istihdamın \% 8,7'sini denk gelmektedir (Uğuz ve Topbaş, 2014: 497). Ayrıca turizm sektörü, dünya GSYH'nin \%10 kadarını oluşturmaktadır (WTTC, 2015; Kaya, 2017: 6). Birleşmiş Milletler Kadın Örgütü ve Dünya Turizm Örgütü tarafından 2010'da hazırlanan "Turizmde Kadın Küresel Raporu”nda kadınların ücretli işe ulaşmalarında ve kadının güçlendirilmesinde olanak sağlama noktasında turizm sektörünün potansiyeline dikkat çekilmiştir (Kaya, 2017: 3).

Genel olarak turizm sektörü incelendiğinde, istihdamın niceliksel olarak etkili fakat işgücü kalitesi bakımından bakıldığında eğitimsiz ve kalifiye olmayan iş gücünün olduğu, kayıt dışı çalışanların oranının fazla olduğu, günlük çalışma saatlerinin yüksek fakat ücretlerin düşük olduğu, sendikalaşma ve toplu iş sözleşmesi kapsama oranının düşük düzeyde olmasından dolayı sosyal diyaloğun da etkili bir biçimde gerçekleşmemektedir (Kaya, 2017: 6).

Turizm sektöründe genel olarak kadınların kalifiye olmayan temizlik gibi kat görevlisi gibi işlerde daha yoğun görülmekteyken, yönetici pozisyonlarına doğru gidildikçe daha az görülmektedirler (Kinnaird ve Hall 1994). Kadın çalışanların yoğunluğunun çok alt seviyelerdeki işlerde olduğu bilinmektedir (Uğuz ve Topbaş, 2014: 498). Sektörün bu yapısal özelliği kuşkusuz sektörde istihdam edilen kadın açısından da belirleyici olmaktadır. Turizm endüstrisinde yapılan işlerin önemli bir bölümü yemek pişirme, karşılama, yatak yapımı, temizlik vb. işler olduğundan ev işlerinin bir uzantısı olarak kabul edilmektedir. Bu nedenle turizm endüstrisi, emek-yoğun kabul edildiği kadar 'kadın-yoğun' iş alanı özelliği de taşımaktadır (Akoğlan, 1996: 17; Cave ve Kılıç 2010: 285). Ayrıca küçük aile işletmeleri şeklinde olan pansiyonlar incelendiğinde ise, kadınlar gerek ücretsiz aile işçisi gerekse mevsimlik işçi olarak, pansiyonun temizlik işlerini, yemek ve bakım hizmetleri ile uğraşmaktadır (Kaya, 2017: 3). Turizm endüstrisinde kadınlar gerek alt pozisyonlarda gerek yönetici pozisyonunda gerekse işletme sahibi olarak birçok sorunla karşılaşmaktadır (Dinçer vd., 2016: 383). 
Kadınlar konaklama sektöründe genel olarak önbüro, insan kaynakları, pazarlama ve banket organizasyonlarında çalışmaktadır. Konaklama işletmelerinde çalışan kadınların genelde üçte biri yönetim kademesinde yer almaktadır. Erkekler çoğunlukla genel müdür, birim müdürü veya şef konumundadırlar (Doherty ve Manfredi, 2001: 68).

Başarılı bir biçimde kadınların turizm sektöründe çalışmalarına örnek verilecek olursa kırsal alanlarda gerçekleştirilen turizm faaliyetlerinde kadınların daha belirgin bir şekilde gerçekleşen geleneksel kadın rol ve görevlerinin ötesinde yeni roller edinmesine imkân sağlamaktadır. Bu duruma örnek olarak, kadınlar kırsal turizmde hem ürünlerin hazırlayıcısı, hem satıcısı durumunda olduklarından kadına istihdam yaratarak, bu yönden de toplumsal kalkınmaya destek vermektedir. Ekonomiye genel olarak bakıldığında, turizm sektörü kadın istihdamı açısından diğer sektörlere göre daha büyük bir paya sahiptir. Turizm endüstrisinde kadın istihdamı diğer sektörler ile kıyaslandığında iki kat daha fazla istihdam sağlamaktadır (Dinçer vd., 2016: 382). Bu durum, çalışma hayatında toplumsal cinsiyet eşitliğini ve kadının güçlendirilmesini desteklemede etkili bir araç konumuna getirmektedir (Kaya, 2017: 5).

\section{Yöntem}

Yapılan bu araştırmanın amacı, kırsal kalkınma bölgelerinde kadın istihdamını incelemek ve karşılaştıkları sorunları belirlemektir. Araştırmanın amacına uygun olarak Afyonkarahisar ilinde termal turizm bölgesi olarak nitelendirilen Gazlıgöl bölgesi araştırma alanı olarak belirlenmiştir. Bu amaç doğrultusunda Gazlıgöl bölgesindeki termal tesislerde istihdam edilen kadınların demografik bilgileri, çalışma koşulları hakkında bilgiler edinilmeye çalışılmıştır. Araştırmanın amacına uygun olarak görüşme yapılabilen kadınlar ile görüşmeler gerçekleştirilmiş, görüşme yapılma imkânının olmadığı kadın çalışanlar ise sadece anket doldurtulmaya çalışılmıştır. Araştırmada veri toplama yöntemi olarak anket tekniği kullanılmıştır. Hazırlanan ankette Köse (2014) çalışmasında kullandığı görüşme formundan faydalanılarak ölçek araştırmanın amacına uygun olarak uyarlanmıştır. Ayrıca oluşturulan ölçek, turizm ve ekonomi alanında uzman olan akademisyenlerin görüş ve önerileri alınmıştır. Oluşturulan ölçeğe ön test uygulanarak düzeltmeler yapılmış ve son haline tamamlanmıştır. Kadın çalışanlara uygulanan anket tekniğinde beşli likert ölçeği tercih edilmiştir. Beşli likert ölçeğinde (1) Kesinlikle Katılmıyorum, (2) Katılmıyorum, (3) Ne Katılıyorum Ne Katılmıyorum, (4) Katılıyorum ve (5) Kesinlikle Katılıyorum şeklinde sıralanan ölçek üzerinde yapmaları istenmiştir. Belirlenen seçeneklerin dişında katılımcıların fikir ve görüşlerini beyan etmeleri ve anket formunda yer almayan görüşlerini de belirleyebilmek amaciyla açık uçlu sorularda yer almaktadır. Oluşturulan ölçek 16 kapalı uçlu ve 3 açık uçlu soru olmak üzere toplam 19 sorudan oluşmaktadır. Gazlıgöl bölgesindeki termal tesislerde istihdam edilen 121 kadın çalışan araştırmanın örneklemini oluşturmaktadır. Elde edilen anket verileri SPSS 24.0 programı ile analizler gerçekleştirilmiş ve mülakatlarda elde edilen veriler raporlanmıştır.

\section{Bulgular}

Araştırmada yöntem olarak anket tekniği uygulanmış, daha ayrıntılı bilgi almak ve ankette yer almayan önermelerin dışında katılımcıların bilgilerine olanak sağlamak amacıyla yüz yüze görüşmeler yapılmıştır. Bu bağlamda ankette yer alan önermelerin birbirleri ile ilişkilerini saptamak amacıyla çapraz tablolar oluşturularak, mülakatlardan elde edilen veriler ile yorumlanmıştır.

Tablo 1. Katılımcıların Çalışmaya Başladıklarındaki Yaşları İle Katılımcıların Eğitim Düzeyleri Arasında Oluşturulan Çapraz Tablo

\begin{tabular}{|c|c|c|c|c|c|c|c|c|}
\hline & & \multicolumn{7}{|c|}{ Katılımcıların Eğitim Durumları } \\
\hline \multirow{8}{*}{ 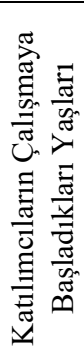 } & & İlkokul & Ortaokul & Lise & Önlisans & Lisans & Lisansüstü & Toplam \\
\hline & $\ldots . .18$ & 2 & 2 & 8 & 3 & 1 & 0 & 16 \\
\hline & 19-22 & 4 & 2 & 19 & 5 & 5 & 0 & 35 \\
\hline & 23-27 & 6 & 8 & 9 & 3 & 2 & 1 & 29 \\
\hline & 28-32 & 4 & 10 & 1 & 0 & 1 & 0 & 16 \\
\hline & 33-37 & 12 & 4 & 0 & 0 & 0 & 0 & 16 \\
\hline & $38, \ldots$. & 7 & 2 & 0 & 0 & 0 & 0 & 9 \\
\hline & Toplam & 35 & 28 & 37 & 11 & 9 & 1 & 121 \\
\hline
\end{tabular}

Tablo 1 incelendiğinde katılımcıların yaşları arttıkça, eğitim düzeylerinin azaldığı görülmektedir. Oluşturulan çapraz tabloda katılımcıların en fazla lise eğitim düzeyindeki 19-22 yaş grubundakiler oluşturmaktadır. Katılımcıların üniversite mezunu olan kişi sayısı toplamda 21 iken, 28 ile 32 yaş grubunda sadece 1 katılımcı üniversite mezunu olup, 33 yaş ve üzeri termal turizm tesislerinde çalışan üniversite mezunu katılımcı bulunmamaktadır. Katılımcılar bu durumun nedenleri olarak ise; erken yaşta evlenmeleri, ailelerinin ekonomik durumlarının iyi olmaması nedeniyle okumadıkları ve kırsal kesimde yaşayan bireylerin kadınların okumasına ön yargılı davranmaları, kırsal kesimde yaşayan ailelerin çocuklarının fazla olmasından dolayı bütün çocukları okutma konusunda ekonomik sıkıntılar yaşamaları gibi nedenlerden dolayı eğitimlerine devam edemediklerini belirtmişlerdir. 
Tablo 2. Katılımcıları Çalışmaya Yönelten Etkenler İle Katılımcıların Eğitim Düzeyleri Arasında Oluşturulan Çapraz Tablo

\begin{tabular}{|c|c|c|c|c|c|c|c|c|}
\hline & & \multicolumn{7}{|c|}{ Katılımcıların Eğitim Durumları } \\
\hline \multirow{7}{*}{ 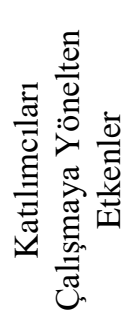 } & & İlkokul & Ortaokul & Lise & Önlisans & Lisans & Lisansüstü & Toplam \\
\hline & Kariyer Hedefi & 2 & 0 & 5 & 4 & 7 & 1 & 19 \\
\hline & Ekonomik Durum & 32 & 25 & 25 & 4 & 1 & 0 & 87 \\
\hline & Sosyal Statü & 1 & 1 & 1 & 2 & 0 & 0 & 5 \\
\hline & Çevre Baskısı & 0 & 1 & 2 & 1 & 0 & 0 & 4 \\
\hline & Diğger & 0 & 1 & 4 & 0 & 1 & 0 & 6 \\
\hline & Toplam & 35 & 28 & 37 & 11 & 9 & 1 & 121 \\
\hline
\end{tabular}

Tablo 2 incelendiğinde katılımcıların ekonomik nedenlerle iş gücü piyasalarında yer alması eğitimlerini yarıda bıraktıkları veya istedikleri düzeyde eğitim alamadıklarını belirtmişlerdir. Oluşturulan çapraz tabloda ekonomik durumlarından dolayı çalışmaya başlayan katılımcıların büyük bir bölümü ilkokul, ortaokul ve lise mezunu oldukları görülmektedir. Ekonomik etkenlerden dolayı çalışan katılımcılardan sadece 5 katılımcının üniversite mezunu olması bu durumu desteklemektedir. Termal turizm tesislerinde çalışan üniversite mezunu olarak 21 katılımcı bulunmaktadır. Üniversite mezunu olan katılımcıların çalışma hayatına başlamalarının nedenleri incelendiğinde 12 katılımcı kariyer hedefi olduğunu, 5 katılımcı ekonomik nedenlerden olduğunu, 2 katılımcı sosyal statü olduğunu, 1 katılımc1 çevre baskısından olduğunu ve 1 katılımcı ise diğer nedenlerden olduğu görülmektedir. Bunun nedenleri ise; katılımcıların erken yaşta evlenmesi, katılımcıların ailelerinin ekonomik durumlarının olmaması, yeni evli olmalarından dolayı borçlarının olması, ekonomik sıkıntılar yaşamaları gibi nedenlerden eğitimlerine devam edemediklerini belirtmişlerdir.

Tablo 3. Katılımcıların Çalışma Konusunda Aldıkları Karara Yardımcı Olan Kişilerin Cinsiyet Durumları İle Katılımcıların Çalışma Konusunda Çevrelerinden Destek Alma Durumları Arasında Oluşturulan Çapraz Tablo

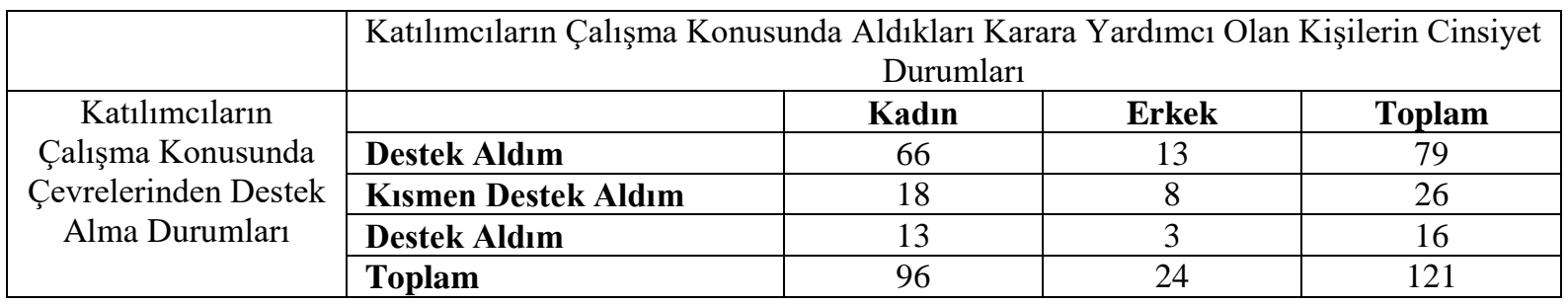

Tablo 3 incelendiğinde katılımcıların büyük bir bölümü destek aldığını veya kısmen destek aldığını belirtmişlerdir. Oluşturulan çapraz tabloda katılımcılara çalışma konusunda aldıkları desteği yine kadın arkadaşlarından gördüğünü ve bu arkadaşlarının da iş gücü piyasasında yer aldığını “ ben yapıyorum sen neden yapamayasın” diyerek motive ettiklerini belirtmişlerdir. Eşlerinden veya aile bireylerinden destek alan katılımcılar ise bu durumun temel nedeni olarak ekonomik sıkıntılar yaşamaları olduğunu belirtmişlerdir. Destek almayan katılımcılar ise, okudukları bölüm gereği evlenmeden öncede iş gücü piyasalarında yer almaları, evlendikten sonrada işlerinde çalışmaya devam ettiklerini ve kariyer hedefi olduklarını belirtmişlerdir.

Tablo 4. Katılımcıların Çalıştıkları Alanı Seçimindeki Etkenler İle Katılımcıların Çalıştıkları İşi Nasıl Bulduklarına İlişkin Durumları Arasında Oluşturulan Çapraz Tablo

\begin{tabular}{|c|c|c|c|c|c|c|c|}
\hline & \multicolumn{7}{|c|}{ Katılımcıların Çalıştıkları Alanı Seçimindeki Etkenler } \\
\hline \multirow{7}{*}{ 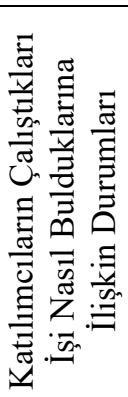 } & & Ücreti & Unvanı & $\begin{array}{l}\text { Çalışma } \\
\text { Saatleri }\end{array}$ & $\begin{array}{l}\text { Çalışma } \\
\text { Ortamı }\end{array}$ & Diğer & Toplam \\
\hline & İnternet İlanı & 6 & 3 & 2 & 5 & 1 & 17 \\
\hline & Gazete İlanı & 1 & 1 & 0 & 1 & 0 & 3 \\
\hline & Afiş İlanı & 1 & 0 & 0 & 0 & 0 & 1 \\
\hline & $\begin{array}{l}\text { Tanıdık } \\
\text { Aracılığıyla }\end{array}$ & 9 & 7 & 17 & 50 & 4 & 87 \\
\hline & Diğer & 3 & 0 & 3 & 4 & 3 & 13 \\
\hline & Toplam & 20 & 11 & 22 & 60 & 8 & 121 \\
\hline
\end{tabular}

Tablo 4 incelendiğinde katılımcıların büyük bir bölümü çalışma saatleri ve çalışma ortamından dolayı tanıdık aracılığıyla işe girdikleri görülmektedir. Araştırmaya katılan 121 katılımcının 87'si tanıdık aracılığıyla işe girmiş ve bu kişilerin 50'si çalışma ortamı ve 17'si çalışma saatlerinin düzenli olması, evi ihmal etmemeleri ve aile ekonomisine katkı sağlayabilmek için çalıştıklarını ifade etmişlerdir. İnternet ilanı ile işe başlayan katılımcılar ise, yine arkadaşlarının sosyal 
medya hesaplarında ilanı paylaşmaları sonucu işletme ile irtibata geçerek işe başladıklarını belirtmişlerdir. Katılımcılar çalışma ortamı olarak bulundukları kasabanın nüfusunun az olması herkesin birbirini tanıması gibi nedenlerden olduğunu belirtmişlerdir.

Tablo 5. Katılımcıların Turizm Sektöründe Çalışmaya Başlamadan Önce Başka Bir Sektörde Çalışma Durumları İle Katılımcıların Çalıştıkları Alanı Seçimindeki Etkenler arasında Oluşturulan Çapraz Tablo

\begin{tabular}{|c|c|c|c|c|}
\hline & \multicolumn{4}{|c|}{$\begin{array}{c}\text { Katılımcıların Turizm Sektöründe Çalışmaya Başlamadan Önce Başka Bir Sektörde Çalışma } \\
\text { Durumları }\end{array}$} \\
\hline \multirow{7}{*}{ 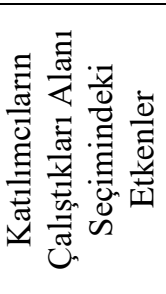 } & & Evet Çalıștım & Hayır Çalıșmadım & Toplam \\
\hline & Ücreti & 9 & 11 & 20 \\
\hline & Unvanı & 8 & 3 & 11 \\
\hline & Çalışma Saatleri & 11 & 11 & 22 \\
\hline & Çalışma Ortamı & 41 & 19 & 60 \\
\hline & Diğer & 5 & 3 & 8 \\
\hline & Toplam & 74 & 47 & 121 \\
\hline
\end{tabular}

Tablo 5 incelendiğinde araştırmaya katılan 121 katılımcının 74'ü termal turizm tesislerinde çalışmadan önce başka sektör ve alanlarda çalıştıklarını ifade etmişlerdir. Katılımcıların çalıştıkları işler genel olarak, temizlik şirketinde, tezgâhtarlık, yemek şirketlerinde, çocuk bakımı gibi işlerde çalışmışlardır. Üniversite mezunu olan katılımcılar, eğitimleri sırasında alışveriş merkezlerinde yarı zamanlı olarak çalıştıklarını, bunun dışında ise ön muhasebe, sekreterlik, müşteri hizmetleri gibi işlerde çalıştıklarını belirtmişlerdir. Daha önce başka sektörde veya alanda çalışan 74 katılımcının çalıştıkları işin ücreti ve unvanından ziyade çalışma saatleri ve çalışma ortamından dolayı işlerini tercih ettiklerini belirtmişlerdir. Daha önce başka bir sektörde ve alanda çalışmayan 47 katılımcının 11'i işin ücretinden dolayı, 3 katılımcı iş yerinin pozisyonu veya unvanından dolayı, 11 katılımcı çalışma saatlerinden dolayı 19 katılımcı çalışma ortamından dolayı ve 3 katılımcı diğer nedenlerden dolayı termal tesislerde çalışmaya başladıklarını belirtmişlerdir.

Tablo 6. Katılımcıların “İşiniz ailenize gereken özeni göstermenizi etkiliyor mu?” Sorusuna Cevap Verme Durumları İle Katılımcıların "Kendinizi iyi bir anne veya iyi bir eş olarak görüyor musunuz?” Sorusuna Cevap Verme Arasında Oluşturulan Çapraz Tablo

\begin{tabular}{|c|c|c|c|c|c|}
\hline \multicolumn{2}{|c|}{} & \multicolumn{3}{|c|}{ Katılımc1ların “İşiniz ailenize gereken özeni göstermenizi etkiliyor mu?” } \\
Sorusuna Cevap Verme Durumları
\end{tabular}

Tablo 6 incelendiğinde araştırmaya katılan 121 katılımcının 97'si kendisini iyi bir eş veya anne olarak görmekte ve bu katılımcılardan 13'ü işinin ailesine göstermesi gereken özeni etkilediğini, 29'u kısmen etkilediğini, 55'i ise etkilemediğini belirtmiştir. 6 katılımcı kendisini iyi bir eş veya anne olarak görmemekte ve bu katılımcılardan 1'i işinin ailesine göstermesi gereken özeni etkilediğini, 1'i kısmen etkilediğini, 4’ü ise etkilemediğini belirtmiştir.

Tablo 7. Katılımcıların “Kazandığınız ücretin büyük bir kısmını nerede kullanıyorsunuz?” Sorusuna Cevap Verme Durumları İle Katılımcıların “Ailenizin çalışmanıza bakış açısı nedir?” Sorusuna Cevap Verme Durumları Arasında Oluşturulan Çapraz Tablo

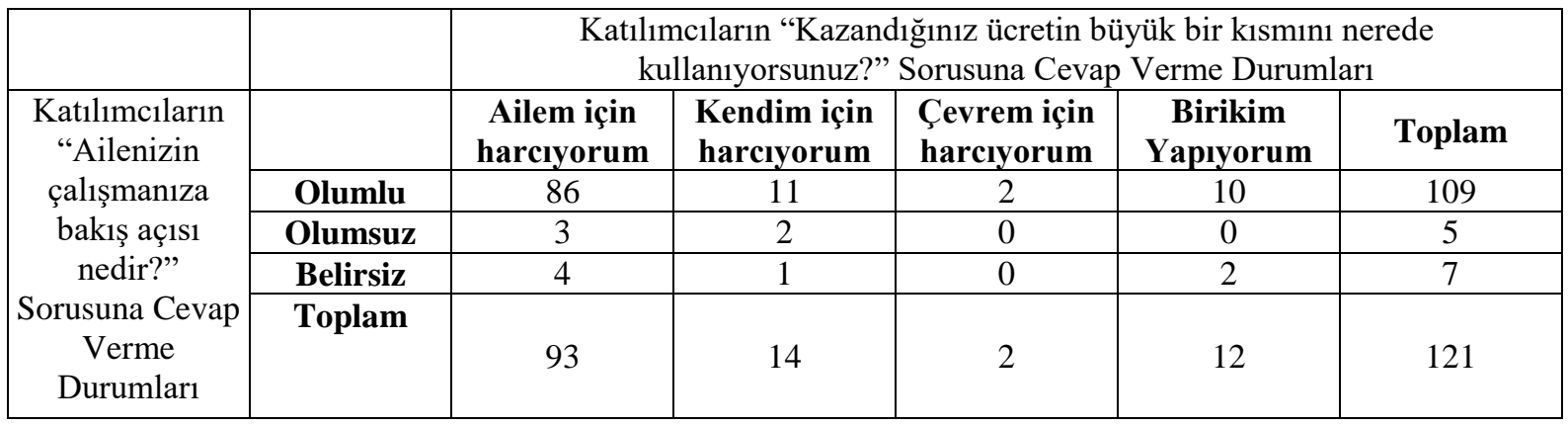


Tablo 7 incelendiğinde araştırmaya katılan 121 katılımcının 109'u çalışmasına ailelerinin olumlu baktığını ve bu katılımcılardan 86'sı kazandığ ücretin büyük bir bölümünü ailesi için harcadığını, 11 'i kendisi için harcadığını, 2'si çevresi için harcadığını, 10'u ise birikim yaptığını belirtmiştir. 5 katılımcının çalışmasına ailelerinin olumsuz baktığını ve bu katılımcılardan 3'ü kazandığı ücretin büyük bir bölümünü ailesi için harcadığını, 2'si kendisi için harcadığını belirtmişlerdir. 7 katılımcının çalışmasına ailelerinin nasıl baktığını bilmediklerini ve bu katılımcılardan 4'ü kazandığı ücretin büyük bir bölümünü ailesi için harcadığını, 1'i kendisi için harcadığını, 2'si ise birikim yaptığını belirtmiştir.

Tablo 8. Katılımcıların “Kazandığınız ücretin büyük bir kısmını nerede kullanıyorsunuz?” Sorusuna Cevap Verme Durumları İle Katılımcıları Çalışmaya Yönelten Etkenler Arasında Oluşturulan Çapraz Tablo

\begin{tabular}{|c|c|c|c|c|c|c|}
\hline & \multicolumn{5}{|c|}{$\begin{array}{c}\text { Katılımcıların “Kazandığınız ücretin büyük bir kısmını nerede } \\
\text { kullanıyorsunuz?” Sorusuna Cevap Verme Durumları }\end{array}$} \\
\hline & & $\begin{array}{c}\text { Ailem için } \\
\text { harcıyorum }\end{array}$ & $\begin{array}{l}\text { Kendim için } \\
\text { harclyorum }\end{array}$ & $\begin{array}{l}\text { Çevrem için } \\
\text { harclyorum }\end{array}$ & $\begin{array}{c}\text { Birikim } \\
\text { Yapıyorum }\end{array}$ & Total \\
\hline \multirow{6}{*}{ 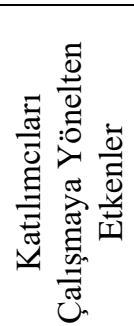 } & Kariyer Hedefi & 12 & 6 & 0 & 1 & 19 \\
\hline & $\begin{array}{l}\text { Ekonomik } \\
\text { Durum }\end{array}$ & 70 & 7 & 2 & 8 & 87 \\
\hline & Sosyal Statü & 4 & 0 & 0 & 1 & 5 \\
\hline & Çevre Baskısı & 2 & 1 & 0 & 1 & 4 \\
\hline & Diğer & 5 & 0 & 0 & 1 & 6 \\
\hline & Toplam & 93 & 14 & 2 & 12 & 121 \\
\hline
\end{tabular}

Tablo 8 incelendiğinde araştırmaya katılan 121 katılımcının 87'si ekonomik nedenlerden dolayı çalışmakta ve bu katılımcılardan 70'i kazandığı ücretin büyük bir bölümünü ailesi için harcadığını, 7'si kendisi için harcadığını, 2'si çevresi için harcadığını, 8'i ise birikim yaptığını belirtmiştir. 19 katılımcı kariyer hedefi olduğundan dolayı çalışmakta ve bu katılımcılardan 12'si kazandığı ücretin büyük bir bölümünü ailesi için harcadığını, 6'sı kendisi için harcadığını, 1'i ise birikim yaptığını belirtmiştir. 5 katılımcı sosyal statüden dolayı çalışmakta ve bu katılımcılardan 4’ü kazandığı ücretin büyük bir bölümünü ailesi için harcadığını, 1'i ise birikim yaptığını belirtmiştir. 4 katılımcı çevre baskısı nedeniyle çalışmakta ve bu katılımcılardan 2'si kazandığ1 ücretin büyük bir bölümünü ailesi için harcadığını, 1'i kendisi için harcadığını, 1'i ise birikim yaptığını belirtmiştir. 121 katılımcının 93'ü kazandığ ücretin büyük bir bölümünü ailesi için harcadığını, 14'ü kendisi için harcadığını, 2'si çevresi için harcadığını, 12'si ise birikim yaptığını belirtmiştir.

Çalışmada açık uçlu soru olan "Turizm sektörünün kadın çalışan için uygun bir sektör olduğunu düşünüyor musunuz? Avantajları ve dezavantajları nelerdir?” sorusuna verdikleri yanıtlar incelendiğinde ön plana çıkan avantajları:

- $\quad$ Erkekler ile kadınların bir arada çalışmasını sağlaması ve cinsiyetçi ayrımın yapılmamasına sağladığı katkı,

- Sosyal çevre oluşturmadaki katkısı,

- Farklı kültüre sahip insanlar ile iletişim kurabilme imkânı ve iletişim kurabilme konusunda sağladığı katkı,

- Bireyin kendini geliştirme konusunda sağladığı katkı,

- İşimkânı sağlaması,

- Çalışma saatlerinin düzenli olması,

- Şehrin gelişmesine sağladığı katkılardır.

Katılımcıların verdikleri cevaplar doğrultusunda ön plana çıkan dezavantajlar ise:

- $\quad$ Turizm sektöründe iş yoğunluğunun belirli dönemlerde yoğunlaşması,

- Düşük sezonlarda ücretsiz izne çıkartılmak,

- Ücretin artmaması veya sınırlı düzeyde artması,

- Termal turizm tesisleri organizasyon şemasında belirli bölümler haricinde kıdem, unvan gibi yükselmelerin olmamas1,

- Kadın çalışanların sadece temizlik, mutfak ve benzeri ev ile uyumlu işlerde yer verilmesi,

- Belirli dönemlerde gece çalışmak zorunda olunması,

- Yoğun dönemlerde yaşanan izin sorunları,

- Patron ve müdürlerin tamamına yakını erkek olması nedeniyle iletişim konusunda yaşanan sorunlar,

- Termal turizm işletmelerinde kadınların yaptıkları temizlik, mutfak gibi işleri aynı ücrete erkeklere yaptıramamaktan dolayı işverenin kadınları ikincil iş gücü olarak görmesi ön plana çıkmaktadır.

Çalışmada açık uçlu başka bir soru olan "Gazlıgöl'ün, çalışan kadınlar için uygun bir yer olduğunu düşünüyor musunuz? Olumlu ve olumsuz yönleri nelerdir?” sorusuna verdikleri yanıtlar incelendiğinde ön plana çıkan olumlu yönleri:

İkamet ettikleri yere yakın olması,

- Erkekler ile kadınların bir arada çalışmasını sağlamasıyla kırsal alanlardaki ön yargının kaldırılmasına sağladığı katk1,

Sosyal çevre oluşturmadaki katkısı,

Personel servisinin olması, 
- Farklı kültüre sahip insanlar ile iletişim kurabilme, yeni şeyler öğrenebilme imkanı ve iletişim kurabilme konusunda sağladı̆̆ı katkı,

- Bireyin kendini geliştirme ve kendine olan güveni artırma konusunda sağladığı katkı,

- $\quad$ İş imkânı sağlaması ve maddi yönden katkı sağlaması,

- Çalışma saatlerinin düzenli olması,

- Ekonomik özgürlük kazandırması ve kendi ayakları üzerinde durabilme yetisini kazanmasına sağladığı katkı,

- Termal suların kullanımı ve hangi hastalıklara iyi geldiği konusunda bilinçlenmeye sağladığı katkı,

- Şehrin gelişmesine ve bilinirliğinin artmasına sağladığı olumlu katkılardır.

Katılımcıların verdikleri cevaplar doğrultusunda ön plana çıkan olumsuz katkılar ise;

- $\quad$ Ücretin düşük olması, oluşmaması,

Gazlıgöl'ün küçük bir yer olması, herkesin birbirini tanımasından dolayı iş yerinde gerekli ciddiyetin

Erkeklerin aynı paraya yapmayacağı işlerde kadınların çalıştırılması, kadının ikincil iş gücü olarak görülmesi,

İş yerinde acil bir durum halinde şehre uzak olması,

Düşük sezonda verilen ücretsiz izinler,

Yüksek sezonda fazla mesai yapma ve bu duruma bağlı olarak evi ihmal etmek,

Termal turizm tesislerinde belirli alanlar dışında yükselme imkânının olmaması,

- Kasaba küçük olduğu için herkesin birbirini tanıması ve yanlış anlamalar vb. nedenlerden dolayı dedikodunun fazla olması olumsuz yönleridir.

\section{Sonuç ve Öneriler}

Yapılan araştırmanın sonuçlarına göre katılımcıların \%29,8 oranına denk gelen 36 katılımcı 2 ile 4 yıl arasında tecrübesi olduğunu ve yaş dağılımları olarak en fazla \%28,9 oranına denk gelen 35 katılımcı 19 yaş ile 22 yaş aralığında olduğu tespit edilmiştir. Bu durumun sonucu olarak termal tesislerde çalışan kadınların sektör tecrübeleri 10 yıldan fazla olan kişi sayısı oldukça azdır. Yapılan mülakatlarda katılımcılar, termal turizm işletmelerinde 35 yaş üzerindeki kadınların işletmelerde çalıştırılmak istenmemesinin en önemli nedeni olarak dinamik iş gücü, genel olarak evli olmayan veya evli olsa bile çocuğu olmayan yükümlülükleri az olan kadınları tercih etmektedir. Bunun dışında ise 35 yaşın üzerindeki kadınların termal turizm işletmelerinde çalışmamalarının nedenleri arasında maaşının düşük olması, evlenme, çocuk yapma, çocuk yetiştirme, eşinin izin vermemesi gibi nedenlerinde olduğunu belirtmişlerdir. Termal turizm işletmelerinde genel olarak temizlik işleri, mutfak işleri, çamaşırhane gibi rutin ev işlerinde yapılan işlerin dışında bahçe işleri gibi işlerde çalıştırıldıklarından dolayı işletmeler belirli yaş aralığındaki işgücünü tercih ettiklerini belirtmişlerdir. Bu durumun yanı sıra işin niteliği ve termal işletmelerin organizasyon şemasında kıdem ve maaşta yükselme olmaması maaşta yükselme olsa bile çok sınırlı düzeyde kalması, çalışan kadınlar açısından termal tesislerde uzun süre çalışmalarının önündeki en önemli engellerdir.

Katılımcıların eğitim durumları incelendiğinde en fazla \%30,6 oranına denk gelen 37 katılımcı lise mezunu olduğu tespit edilmiştir. Katılımcıların \%28,9 oranına denk gelen 35 katılımcı ilkokul, \%23,1'ine denk gelen 28 katılımcı ortaokul mezunudur. Katılımcılar eğitimlerini tamamlayamadıkları için termal turizm tesislerinde temizlik, bulaşık, çamaşırhane, mutfak gibi ev işleri benzeri işlerde istihdam edilmektedir. Eğitim seviyesinden kaynaklı iş gücü piyasasında iş bulmanın zor olduğunu, düşük ücretli bu işlerde çalışmak zorunda kaldıkları yaşadıkları sıkıntılardandır.

Katılımcıları çalışmaya yönelten etkenler başında katılımcıların \%71,9 oranına denk gelen 87 katılımcı ekonomik durumlarından dolayı çalıştıklarını belirtmişlerdir. Katılımcılar ekonomik nedenler olarak; yeni evli olanların borçlarının veya taksitlerinin olması, ikamet ettikleri yerlerin genelinde iş imkânlarının kısıtlı olması ve olan işlerin maaşının düşük olması, tek maaşın ev geçimine yetmemesi ve aile ekonomisine katkı sağlama isteği, çocuğu olmayan yeni çiftlerin veya bekâr kişilerin birikim yapmak istemeleri, çocuklu ailelerin masraflarının fazla olması, evlerinin kira olması gibi ekonomik nedenler ön plana çıkmaktadır. Aynı zamanda katılımcıların \%65,3 oranına denk gelen 79 katılımcı çalışma konusunda ailesinden veya çevresinden destek aldığını belirtmiştir. Bu desteğin yine kadınlar tarafından sağlandığını belirtmişlerdir. Katılımcılara çalışmaları konusunda termal turizm tesislerinde istihdam edilen arkadaşlarının aracılık yaptığını, motive ettiğini belirtmişlerdir. Bu durumu destekleyen başka bir sonuç ise katılımcıların çalıştıkları işi bulma şekilleri incelendiğinde en fazla \% 71,9 oranına denk gelen 87 katılımcı tanıdık aracılığıyla işi bulduklarını belirtmeleridir. Katılımcıların çalıştıkları işi, tanıdık vasıtasıyla bulması onların iş ortamına daha çabuk uyum sağladığını ve çalışma konusunda ailelerini daha kolay ikna ettiklerini belirtmişlerdir.

Araştırmanın diğer sonuçları ise, çalışan kadınların kendilerini iyi bir anne veya iyi bir eş olarak gördükleri, evlerinde eşiyle birlikte ortaklaşa söz sahibi olduklarını, kazandıkları parayı yine aile ekonomisine katkı sağlaması amacıyla kazandıklarını ve kazandıkları paranın büyük bir bölümünü yine ailelerine harcadıklarını belirtmişlerdir. Termal turizm tesislerinde çalışan kadınların büyük bir bölümü ilkokul, ortaokul ve lise mezunu olduğu görülmektedir. Yine bu kadınların termal turizm tesislerinde çalışmadan önce temizlik şirketinde, tezgâhtarlık, yemek şirketlerinde, çocuk bakımı gibi işlerde çalışmışlardır. Üniversite mezunu olan katılımcılar, eğitimleri sırasında alışveriş merkezlerinde yarı zamanlı olarak çalıştıklarını, bunun dışında ise ön muhasebe, sekreterlik, müşteri hizmetleri gibi işlerde çalıştıklarını belirtmişlerdir. Yapılan mülakatlarda ön plana çıkan sonuç olarak, kırsal alanlarda iş imkânları kısıtlı olduğu için aynı ücrete erkeklerin çalışmayı kabul etmediği bu nedenle temizlik mutfak gibi işlerde kadınların çalıştırılmakta, bu durumda işverenler tarafında kadınların ikincil iş gücü olarak görülmektedir. 
Yapılan bu araştırmanın sonuçları doğrultusunda öneriler ise;

- Kadın çalışanların iş gücü piyasalarında daha fazla yer almalarını sağlamak amacıyla ilgili kurum ve kuruluşların bir araya gelerek düzenlemeler yapılmalı ve gerekli teşvikler sağlanmalıdır.

- $\quad$ İlgili kurum ve kuruluşlar kırsal kesimlerin kalkınabilmesi için kısa ve uzun vadeli planlamalar ve stratejiler geliştirmelidir.

- Kırsal turizm alanında değerlendirilebilecek yerler belirlenmeli ve bu yerlerde yaşayan insanlar kırsal turizm konusunda bilinçlendirilmelidir.

- Kırsal alanlarda yaşayan bireylere tarihi bilgiler, yörenin özellikleri, yabancı dil gibi kırsal turizmi destekleyici, geliştirici konularda eğitimler verilmelidir.

- İlgili kurum ve kuruluşlar kadının toplumdaki yerini savunacak ve geliştirecek, cinsiyetçi ayrımı ortadan kaldıracak düzenlemeler ve uygulamalar geliştirilmelidir.

- Çalışan kadınların sosyal haklarını bilme konusunda bilinçlendirilmeli, kayıt dışı istihdamın önünde geçilmelidir. 
Ahipaşaoğlu, S., ve Çeltek, E. 2006. Sürdürülebilir Kırsal Turizm, Gazi Kitabevi. Ankara.

Akoğlan, M. K. 1996. Konaklama Endüstrisinde Kadının Konumu, Anatolia Turizm Araştırmaları Dergisi, 7 (3-4): 1623.

Ateş, A., Sunar, H. ve Kılınç, Çağlar C. 2018. Turizm Sektöründe E - Ticaret ve Uygulamalara Yönelik Öneriler, Social Sciences Studies Journal (SSSJournal) Vol:4 Issue:28 pp:6591-6597.

Bahar, O. 2013. “Turizm Sektörü-Ekonomi Illişkisi”, Editör: Metin Kozak, Turizm Ekonomisi, Anadolu Üniversitesi Yayınları, Eskişehir, ss. 2-26.

Cave, P. ve Kılıç, S. 2010. The Role of Women in Tourism Employment with Special Reference to Antalya, Turkey, Journal of Hospitality Marketing \& Management, 19 (3): 280-292.

Çolak, Faruk Ö. 2003. Sanayileşme ve Kadın işgücü, istihdam. Kadın İşgücü ve Yeni İş Kanunu Sempozyumu, Muğla.

Deane, P. 1994. İlk Sanayi İnkılabı, Çeviren: Tevfik Güran, Türk Tarih Kurumu Yayınevi, Ankara.

Dinçer, F. İ., Akova, O., Ertuğral, S. M. ve Çifçi, M. A. 2016. Woman Labour in Tourism Industry in Turkey: Opportunities And Barriers, Eurasian Academy of Sciences Social Sciences Journal, Volume:S1: 379-395

Doherty, L., ve Manfredi, S. 2001. Women's employment in Italian and UK hotels. International Journal of Hospitality Management, 20(1), 61-76.

Geray, C. 1999. Kırsal Kalkınma Yöneltileri, Illçe Yerel Yönetimi ve İlçe Köy Birlikleri, Çağdaş Yerel Yönetimler Dergisi, C.8, Sayı: 2, Ankara.

Kaya, Ş. 2017. Turizmde Kadın Emeği, KARATAHTA İş Yazıları Dergisi, Sayı: 9/ Aralık 2017, s. 1-22

Kinnaird, V., ve Hall, D. R. (Eds.). 1994. Tourism: A gender analysis. * Belhaven Press.

Köse, Z. 2014. Turizmde Kadın İstihdamı Ve Kadın Girişimciliği Beypazarı Örneği, Hacettepe Üniversitesi Sosyal Bilimler Enstitüsü Antropoloji Anabilim Dalı, Ankara.

Oakley, P., ve Garforth, C. 1985. Guide to extension training(No. 11). Food \& Agriculture Org..

Tokol, A., 1999. Dünya'da Kadın İşgücü, TİSK, Türkiye'de Kadın İşgücü Seminerleri I-II, 28 Nisan 1999, Bursa.

Tolunay, A. ve Akyol, A. 2006. Kalkınma ve Kırsal Kalkınma: Temel Kavramlar ve Tanımlar, Süleyman Demirel Üniversitesi Orman Fakültesi Dergisi Seri: A, Sayı: 2, Y1l: 2006, ISSN: 1302-7085, Sayfa: 116-127.

Uğuz, S. Ç., Ve Topbaş, F. 2016. Turizmde Kadın İstihdamı ve Ücret Ayrımıılığı: Karşılaştırmalı Bir Analiz. Anatolia: Turizm Araştırmaları Dergisi, 27(1). 